\title{
Medication Administration Error in Anaesthetic Practice: AReview of the African Experience
}

\author{
${ }^{1}$ Rotimi Kunle, ${ }^{2}$ Aleku A Godwin, ${ }^{3}$ Obamiro Kehinde, ${ }^{4}$ Daniel Abraham \\ ${ }^{\prime}$ (Department of Pharmacology, College of Medicine, University of Lagos Nigeria) \\ ${ }^{2}$ (Directorate of Enforcement, National Agency for Food and Drug Administration and Control) \\ ${ }^{3}$ (Department of Clinical Pharmacy, Faculty of Pharmacy, University of Lagos Nigeria) \\ ${ }^{4}$ (Department of Pharmacy, School of Medicine, University of Tasmania, Australia)
}

\begin{abstract}
Medication error is a significant issue of concern in medical practice because it can lead to severe and deleterious reaction. The issue is of more concern in anaesthetic practice in which medications are administered to interfere with the normal activity of the central nervous system so as to prevent pain associated with medical procedures. This papers reviews record of anaesthetic medication administration error in the African setting drawing from records of contemporary databases. Also the likely causes were enumerated and recommendations to ensure best practices. Overall 9 publications comprising 7 studies and 5 case reports were accessed from 3 countries (i.e. Nigeria, South Africa and Morocco). These error can be adequately checked by double checking of all medication label by a minimum of two Anaesthetist prior to administration, reducing Anaesthetics work load and introducing colour coding of syringes into national guidelines.
\end{abstract}

Keywords:medication error, anaesthetic, colour coding, iatrogenic

\section{Introduction}

The crucial roles of medicines in the prevention and treatment of diseases are well appreciated; they are life-saving and can greatly improve the quality of life when used appropriately. However, the administration of medicinal products may be accompanied by avoidable undesirable effects which sometimes arelifethreatening,especially when administered in error. Medication errorsare preventable events that may lead to inappropriate medication use causing varying degrees of harm to patients ${ }^{[1]}$. These undesirable effectsarecommon in healthcare system andcan occur across the spectrum of activitiesrelating to prescribing, dispensing, transcribing and administration of medicines, with prescribing errors highlighted as the most frequent in medical practice. ${ }^{[2]}$ Medication errors are said to be a known concern in the hospital setting leading to various degree of harm in patient. ${ }^{[3]}$ The magnitude of harm caused to patients due to medication errors is significant and it is considered to be the most prevalent of all medical errors ${ }^{2]}$ with an estimated 7000 deaths per year in the US alone ${ }^{[4]}$ Other studies have recorded that $1-2 \%$ of patients in UK and US hospitals have been expose to iatrogenic harm leading to increase in mortality as a result of medication errors. ${ }^{[5,6,7]}$ Medication error do not only lead to increased morbidity and mortality but also contribute to longer hospital stay, additional healthcare cost. Additional healthcare cost as a result of medication related event has been estimated to be up to $\$ 1.5$ million in a single facility comprising of both medication error and adverse drug reaction. ${ }^{[8]}$ Medication errormay also serve as a potential cause for litigation and erosion of public confidence in healthcare delivery systemas such it is a serious concern that needs to be addressed at every level of care. ${ }^{[9,10,11]}$

Medication error occurs in every field of medical practice and may actually be particularly more serious and sometimes irreversible in anaesthetic practice. With the advent of safer anaesthetic agents and overall improvement in the quality of anaesthetic practice, the management ofanaesthesia in general has improved in the last few decades. However, the complex working environment involving different medical and paramedical personnel and the need to use several drugs in combination in the practice may directly or indirectly drive the occurrence of medication errors in anaesthetic practice settings.

In most parts of Africa, theseimprovements have not been replicated as access to modernequipment, safer drugs and quality monitoring are severely limited. The cascade of these factors makes it more likely for medication errors to occur in the African anaesthetics practice settings.

Medication error reporting should be a common practice among health workers, however this is not the casein many settings as many errors go unreported due to number of factors including practice settings limitations, lack of reporting and data collection format, population variation, lack of a consensus definition of what constitute an error and the avoidance of defamation of colleagues and practices. ${ }^{[12]}$

Surveys of the occurrence of medication errors inanaesthetic practice in anumber of countries showsignificant variations. While only $30 \%$ of the members of the Canadian Society of Anaesthesiologists admitted experiencing errors in their lifetime career ${ }^{[13]}, 89 \%$ anaesthesiologists in New Zealand admitted 
making an error in practice ${ }^{[14]}$ and these figure still varies when compared with data from other advance countries.

Record keeping in African anaesthetic practices is quite poor as highlighted in an audit ${ }^{[15]}$ hence medication errors data in this region is reasonable poor. ${ }^{[9,16]}$

Several methods have been employed forcollecting data on medication errors and these methods with their associated advantages and caveats have been reviewed. ${ }^{[5,17]}$ In general two approaches are popular in the study of this subject: retrospective review of critical incident reports and a prospective study. Though the prospective study of medication errors may give more accurate error rates, it is limited to a smaller population as such serious incidents may not be captured and these areadequately addressed in retrospective reviews.

In the methodology for this systematic review, case report, retrospective and prospective studies and all studies relating to medication administration error in anaesthetic practice in the Africa clinical setting were accessed and discussed. Also factors contributing to errors were highlighted and general recommendations to prevent errors wereproposed.

\section{Search strategy}

\section{Method}

A systematic review of literature relating to Medication administration error in anaesthetic practice across Africa was conducted between November 2013 to April 2014. The following electronic databases were searched: Embase (1974- April 2014), Pubmed (1950 - April 2014), Scopus(1966 - April 2014) and the Cumulative Index to Nursing \& Allied Health Literature (CINAHL) (1982 - October 2011). The search protocol included all ages, all languages, and all types of studies. References of eligible articles were further hand search so as to uncover other relevant articles.

\section{Search terms}

The following keywords were used as search terms: medication error(s), administration error(s),anaesthetic error(s) and anaesthesia error with "Africa" and list of Africa countries.

\section{Inclusion/exclusion criteria}

Articles were included if the aim of the study was to report drug administration error in anaesthetic practice or to report adverse effect as a result of medication use in anaesthesia practice. Articles were excluded if it did not focus on drug administration error in anaesthetic practice and if study or case report was conducted outside of Africa. All letters, conference papers, opinions, reports or editorial papers were also excluded.

\section{Result}

The result summary is shown in figure 1 below . The majority of Africa countries have no documented report of drug administration error in anaesthetic practice with the exception of Nigeria, South Africa and Morocco. More than 450 articles were excluded, as the papers were either not related to Africa countries or not relevant to anaesthetic error. 112 articles were then left for full-text review. Furthermore 103articles were excluded because they were not relevant to the topic, not related to Africa countries or were opinion articles, letters or editorials. 9 articles were identified which comprises of 7 studies and 5 case report . 


\section{Figure 1}

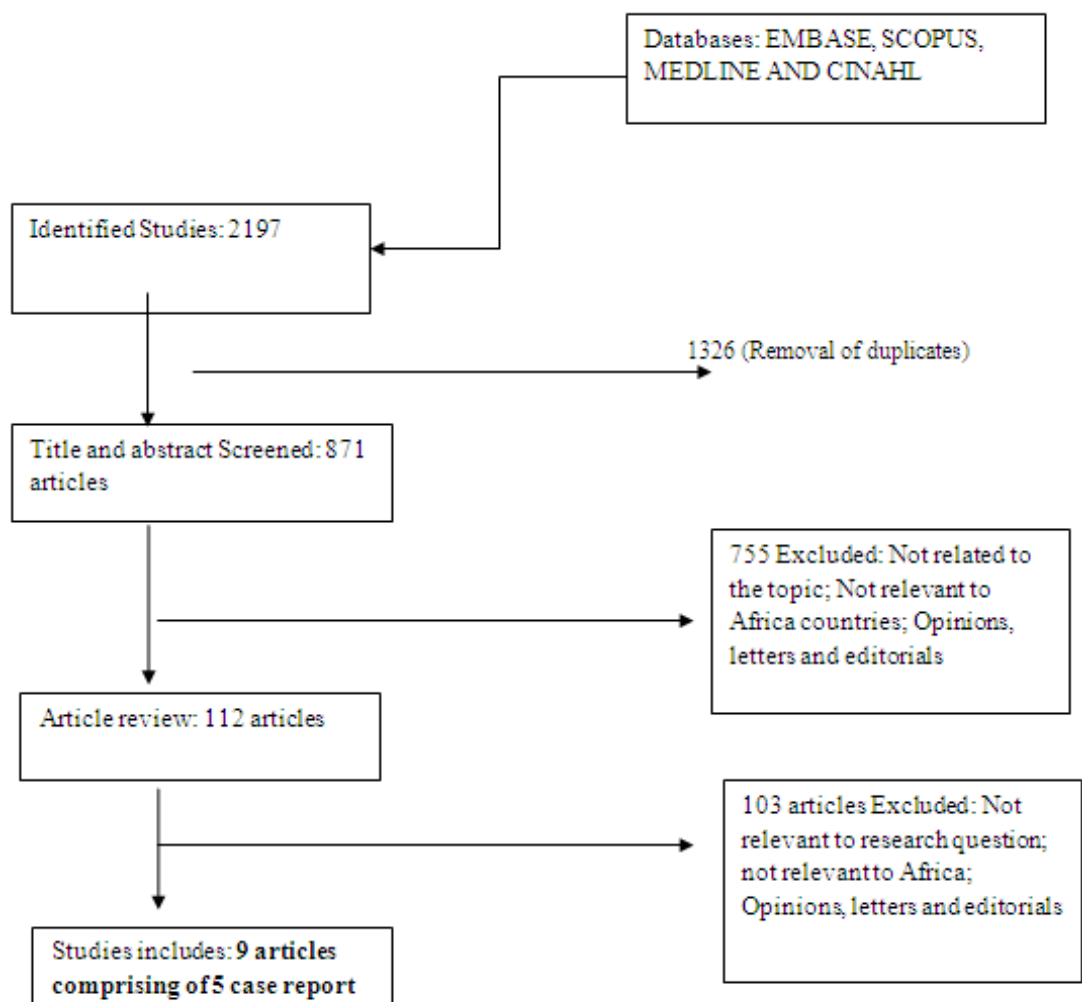
and 7 studies.

Table 1: Case report on Medication Error

\begin{tabular}{|c|c|c|c|c|c|c|}
\hline No & $\begin{array}{l}\text { Country } \\
\text { Setting }\end{array}$ & Method & Medication involved & Management & Type of error & Reference \\
\hline 1 & Nigeria & Case report & $\begin{array}{l}\text { Pancuronium bromide injection } \\
4 \mathrm{mg} \text { being administered } \\
\text { intravenously, instead of } \\
\text { suxamethonium r chloride } \\
\text { injection in a } 50 \text { year old male } \\
\text { farmer. }\end{array}$ & $\begin{array}{l}\text { At the end of the procedure } \\
\text {, residual paralysis was managed } \\
\text { with } \\
\text { neostigmine and atropine He } \\
\text { recovered fully with no adverse } \\
\text { consequence. }\end{array}$ & Substitution & Ogboli $^{(18)}$ \\
\hline 2 & Nigeria & Case report & $\begin{array}{l}\text { In a } 2 \text { year old girl with } \\
\text { Retinoblastoma } \\
\text { booked for enucleation, } 100 \mathrm{mg} \\
\text { of thiopentone sodium was } \\
\text { administered in place of } 25 \mathrm{mg} \\
\text { of the same } \\
\text { drug because Thiopentone } 1 \mathrm{gm} \\
\text { vial was mistaken for } \\
\text { Thiopentone 500mg vial. }\end{array}$ & $\begin{array}{l}\text { Ventilation had to be assisted } \\
\text { for over } 10 \text { minutes until } \\
\text { spontaneous } \\
\text { respiration resume. }\end{array}$ & Dose & $\underset{(18)}{\text { Ogboli }}$ \\
\hline 3 & Nigeria & Case report & $\begin{array}{l}\text { Intravenous injection of } \\
\text { ketamine hydrochloride instead } \\
\text { of suxamethonium } \\
\text { hydrochloride during a } \\
\text { ceaserean operation after the } \\
\text { effect of bupivacaine wore off } \\
\text { in a 33 year Old woman }\end{array}$ & $\begin{array}{l}\text { Quick ventilation with } \\
\text { oxygen after patient } 100 \% \\
\text { unresponsive and } \\
\text { breathing. } \\
\text { continued till sentilation } \begin{array}{r}\text { wasped } \\
\text { consciousness recovered }\end{array} \\
\text { started spontaneous } \\
\text { breathing. There after surgery } \\
\text { was concluded without further } \\
\text { complications. }\end{array}$ & Substitution & $\begin{array}{l}\text { Mato \&F } \\
\text { yneface- } \\
\text { Ogan } \\
(19)\end{array}$ \\
\hline 4 & Nigeria & Case report & $\begin{array}{l}\text { Injection of suxamethonium } \\
\text { chloride instead of ketamine } \\
\text { hydrochloride as } \begin{array}{l}\text { analgesic } \\
\text { supplement after administering }\end{array} \\
\text { intravenous propofol infusion in a } \\
15 \text { year old girl with left breast }\end{array}$ & $\begin{array}{l}\text { Immediate cessation of respiration } \\
\text { was observed. } 100 \% \text { oxygen via } \\
\text { facemask was administered, after } \\
\text { which she was intubated. Manual } \\
\text { ventilation with oxygen was } \\
\text { continued }\end{array}$ & Substitution & $\begin{array}{l}\text { Mato \&Fy } \\
\text { neface- } \\
\text { Ogan } \\
(19)\end{array}$ \\
\hline
\end{tabular}




\begin{tabular}{|c|c|c|c|c|c|c|}
\hline & & & lump excisional biopsy. & $\begin{array}{l}\text { spontaneous respiration begun, and } \\
\text { she patient was allowed to continue } \\
\text { breathing } 100 \% \\
\text { oxygen spontaneously through the } \\
\text { endotracheal tube. } \\
\text { The procedure was } \\
\text { completed successfully with out } \\
\text { further issues. }\end{array}$ & & \\
\hline 5 & Nigeria & Case report & $\begin{array}{lr}\text { Inadvertent intravenous } & \text { injection } \\
\text { of } & 100 \mathrm{mg} \\
\text { ketamine hydrochloride ror } & \text { for } \\
\text { muscle relaxation instead } \\
\text { of suxamethonium hydrochloride. }\end{array}$ & $\begin{array}{l}\text { Not reported as there was no adverse } \\
\text { consequence }\end{array}$ & Substitution & $\begin{array}{l}\text { Mato \&Fy } \\
\text { neface- } \\
\text { Ogan }^{(19)}\end{array}$ \\
\hline
\end{tabular}

Table 2: Studies on Medication Administration Error in Anaesthetic Practice

\begin{tabular}{|c|c|c|c|c|c|}
\hline & Country & Nature of study & Sample & Outcome & Reference \\
\hline 1 & Nigeria & $\begin{array}{l}\text { Multicentrecross-sectional } \\
\text { survey conducted } \\
\text { among physician } \\
\text { anesthetists and nurse } \\
\text { anesthetists } \\
\text { practicing in the major } \\
\text { secondary and tertiary } \\
\text { hospitals in North Western } \\
\text { Nigeria City. }\end{array}$ & $\begin{array}{l}43 \quad \text { (physician } \\
\text { anaesthetists and nurse } \\
\text { anaesthetists). Response } \\
\text { rate was } 86 \% \text {. }\end{array}$ & $\begin{array}{l}\text { Twenty four of the respondent } \\
\text { admit to have made medication error, and } 34 \\
\text { of them remarked that the medication error } \\
\text { was due to look alike } \\
\text { drug labels from manufacturers. According } \\
\text { to the study, untoward sequelae resulted in } \\
44 \% \text { of the } \\
\text { patients that were affected by these } \\
\text { medication errors ranging from cardiac arrest } \\
\text { to delayed recovery from } \\
\text { anaesthesia. } \\
\text { Continuous vigilance, double checking of } \\
\text { drug labels, and colour coding of syringes } \\
\text { was recommended as measures of } \\
\text { minimizing medication errors in their } \\
\text { practice. }\end{array}$ & $\begin{array}{l}\text { Nwasor } \\
\mathrm{al}^{(20)}\end{array}$ \\
\hline 2 & $\begin{array}{l}\text { South } \\
\text { Africa }\end{array}$ & $\begin{array}{l}\text { Confidential self-reporting } \\
\text { survey was posted } \\
\text { and sent electronically to all } \\
720 \text { anaesthetists registered } \\
\text { with } \\
\text { the South African Society of } \\
\text { Anaesthesiologists (SASA) } \\
2004 \text {. }\end{array}$ & $\begin{array}{lr}\text { A total of } & 133 \\
\text { questionnaires } & \text { were } \\
\text { returned for } & \\
\begin{array}{l}\text { analysis } \\
\text { response rate). }\end{array} & (18.5 \%\end{array}$ & $\begin{array}{l}\text { Of the respondents, } 125(94 \%) \\
\text { admitted to having inadvertently } \\
\text { administered a wrong } \\
\text { drug. Thirty respondents }(22.6 \%) \text { said they } \\
\text { had made errors } \\
\text { on at least four occasions. A total of } 303 \\
\text { specific wrong drug } \\
\text { administrations were described. Nearly } 50 \% \\
\text { involved muscle } \\
\text { relaxants. A further } 43 \text { incidents (14\%) } \\
\text { involved the erroneous } \\
\text { administration of vasoactive drugs. Five } \\
\text { deaths and } 3 \text { nonfatal } \\
\text { cardiac arrests were reported. In } 9.9 \% \text { of } \\
\text { incidents the } \\
\text { anaesthetic time was prolonged by more than } \\
30 \text { minutes. } \\
\text { Contributory causes identified included } \\
\text { syringe swaps } \\
(40 \%) \text { misidentification of drugs ( } 27.1 \%) \text {, } \\
\text { fatigue ( } 14.1 \%) \text {, } \\
\text { distractions ( } 4.7 \%) \text {, and mislabelling of } \\
\text { syringes ( } 4.7 \%) \text {. Only } \\
19 \% \text { of respondents regularly use colour- } \\
\text { coded syringe labels } \\
\text { complying with the national standard. }\end{array}$ & $\begin{array}{l}\text { Gordon } \\
\mathrm{al}^{(21)}\end{array}$ \\
\hline 3 & $\begin{array}{l}\text { South } \\
\text { Africa }\end{array}$ & $\begin{array}{l}\text { A confidential self-reporting } \\
\text { survey was sent out to all } \\
\text { members in } \\
\text { the department in which } \\
\text { details were sought of } \\
\text { incidents of wrong } \\
\text { drug administrations }\end{array}$ & 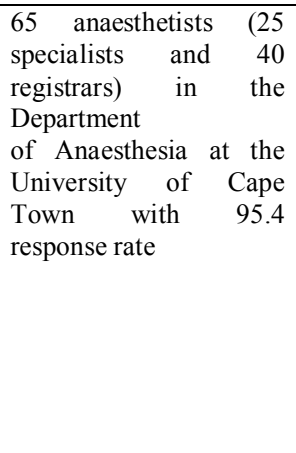 & $\begin{array}{l}93.5 \% \text { of respondents admitted to having } \\
\text { administered the wrong drug at some stage of } \\
\text { their anaesthetic career. } 19 / 62(30.6 \%) \text { have } \\
\text { injected the wrong drug or the correct drug } \\
\text { into the wrong site on at least three } \\
\text { occasions. } \\
56.9 \% \text { of incidents involved muscle } \\
\text { relaxants with suxamethonium chloride } \\
\text { administered instead of fentanyl accounting } \\
\text { for } \\
\text { nearly a third of cases. } 17.6 \% \text { of reported } \\
\text { incidents were classified as being dangerous, } \\
\text { with the potential to cause either severe } \\
\text { haemodynamic instability and / or }\end{array}$ & $\begin{array}{l}\text { Gordon } \\
\mathrm{al}^{(22)}\end{array}$ \\
\hline
\end{tabular}


Medication Administration Error in Anaesthetic Practice: A Review of the African Experience

\begin{tabular}{|c|c|c|c|c|c|}
\hline & & & & neurological damage or seizures. & \\
\hline 4 & Nigeria & $\begin{array}{l}\text { Retrospective } r \text { study } \\
\text { involving all patients who } \\
\text { had undergone surgery as } \\
\text { elective procedures using a } \\
\text { general or regional } \\
\text { anaesthetic } \\
\text { within a twelve month } \\
\text { period }\end{array}$ & $\begin{array}{l}\text { Retrospective study of } \\
\text { eight hundred and } \\
\text { ninety-five elective } \\
\text { surgical procedures (12 } \\
\text { month study) }\end{array}$ & $\begin{array}{l}\text { Five patients were reported as being involved } \\
\text { in errors of drug administration. Drugs } \\
\text { involve are pancuronium, o xytocin, } \\
\text { neostigmine, metoclopramide and } \\
\text { lignocaine/bupivacaine. } \\
4 \text { Junior registrars and } 1 \text { senior registrar } \\
\text { were involved in the respective cases. Poor } \\
\text { theatre light, syringe swap and ampoules } \\
\text { swap were recorded as cause of error. Timely } \\
\text { intervention by senior anaesthetist ensured } \\
\text { success in all of the procedures. }\end{array}$ & $\begin{array}{l}\text { Amucheazi\& } \\
\text { Ajuzieogu } \\
(23)\end{array}$ \\
\hline 5 & $\begin{array}{l}\text { South } \\
\text { Africa }\end{array}$ & $\begin{array}{l}\text { Anonymous questionnaires } \\
\text { were distributed to doctors } \\
\text { performing anaesthesia in } \\
\text { public hospitals in the Free } \\
\text { State }\end{array}$ & $\begin{array}{l}188 \text { doctors at } 22 \text { public } \\
\text { sector hospitals }\end{array}$ & $\begin{array}{l}48.8 \% \text { were medical officers, and } 39.3 \% \text { of } \\
\text { participants have being involved in at least } \\
\text { one event of wrong drug administration. } \\
\text { Registrars and specialists reported the most } \\
\text { errors. Most events were of no clinical } \\
\text { significance and did not cause any permanent } \\
\text { harm to patients. The drugs mostly involved } \\
\text { are fentanyl and suxamethonium. }\end{array}$ & $\begin{array}{l}\text { Lambuschagn } \\
\text { e et } \mathrm{al}^{(24)}\end{array}$ \\
\hline 6 & $\begin{array}{l}\text { South } \\
\text { Africa }\end{array}$ & $\begin{array}{l}\text { Prospective study to } \\
\text { determine the incidence of } \\
\text { drug administration errors } \\
\text { by anaesthetists at three } \\
\text { tertiary South African } \\
\text { hospitals. } \\
\text { Hospital Aospitals. } \\
\text { predominatly manage adult } \\
\text { patient while Hospital B is a } \\
\text { peadiatric hospital. }\end{array}$ & $\begin{array}{l}\text { A total of } 30,412 \\
\text { anaesthetics } \quad \text { were } \\
\text { administered during the } \\
6 \text { month study period. }\end{array}$ & $\begin{array}{l}\text { The response rate and combined incidence of } \\
\text { errors and near-misses was as follows: } \\
\text { Hospital A } 48.8 \%(1: 320) \text {, B } 81.3 \%(1: 252) \\
\text { and C } 48.1 \%(1: 250) \text {. Total response rate was } \\
53 \% \text { and the combined incidence of drug } \\
\text { administration error was } 1: 274 \text {. The most } \\
\text { common errors were as a result of } \\
\text { substituting one drug for another. At the } \\
\text { paediatric hospital, incorrect dose was as } \\
\text { common as substitution. According to the } \\
\text { study, } 36.9 \% \text { of errors were due to drug } \\
\text { ampoule misidentification and } 21.3 \% \text { were } \\
\text { due to syringe identification errors. }\end{array}$ & $\begin{array}{l}\text { Llewellyn et } \\
\mathrm{al}^{(25)}\end{array}$ \\
\hline 7 & Morroco & $\begin{array}{l}\text { Prospective study was } \\
\text { carried out in nine hospitals } \\
\text { affiliated to four university } \\
\text { hospitals. }\end{array}$ & $\begin{array}{l}9199 \quad \text { anesthetic } \\
\text { procedures } r \text { were } \\
\text { reported (mean response } \\
\text { of } 36 \%) . \quad \text { General } \\
\text { anesthesia was } \\
\text { performed in } 75 \% \text { of } \\
\text { patients. } \\
(9 \text { month study) }\end{array}$ & $\begin{array}{l}\text { Sixteen cases of drug errors were reported. } \\
\text { The drugs involved were dominated by } \\
\text { hypnotics. Medication errors were mainly } \\
\text { due to labeling mistakes and attention deficit } \\
\text { due to fatigue and stress. Majority of the } \\
\text { errors were substitution error and errors were } \\
\text { mainly made by the less experienced } \\
\text { practitioners. }\end{array}$ & Amor et $\mathrm{al}^{(26)}$ \\
\hline
\end{tabular}

\section{Discussion}

Our results highlightpoor reporting of medication error in African anaesthetics practice. We carried out thorough searches of published reports across different databases but found only 9 publications comprising 7 studies and 5 case reports. This finding is in tandem with previously filed reports pinpointing under-reporting of medication errors. ${ }^{[27,28,29]}$ This under reporting of medication error can negatively impart on rational use of anaesthetic medication and increase medication related iatrogenic harm. Medication error reporting in anaesthetic practice can be encouraged by providing incentive per report and by encouraging reporting on an anonymous basis as knowledge gained will be beneficial in the management of future patient.

In all of the cases highlighted above, all the patient recovered fully and no significant harm or death occurred. This is in contrast to reports from other part of the world that has recorded death in anaesthetic practice. ${ }^{[13,21]}$ This implies that there is need to begin to carry out research on anaesthetic as a likely cause of death in hospitalized patient.

From the result above, medication administration error in anaesthetic practice is said to be frequently caused by lookalike drug label. ${ }^{[20,22,23]}$ The onus lies on Pharmaceutical companies to ensure that medication use in anaesthetic practice especially those for intravenous administration comes in defined and easily differentiated vials of various shapes, cap colour and sizes so as to assist the practicing anaesthetics to easily differentiate vials even in the case of an emergency.

The second major cause of medication error is wrong labelling of syringes. The practice of using colour coded syringe needs to be employed across practice setting in Africa so as to minimize this type of error. From the review conducted, South Africa is the only country that use this principle to differentiate anaesthetic medication. Specific coloursare being use to differentiate anaesthetic medication according to an agreed national standard. ${ }^{[22,24]}$

Other factors that have been highlighted as possible causes of medication error in anaesthetic practice include fatigue and distraction. Effort should be made by all stakeholders to ensure that the anaesthetic practice setting across Africa be made as convenient and comfortable as possible with adequate power, ventilation and 
lightening. Also anaesthetist should not be overworked in their respective practice so as to minimize the risk of error. ${ }^{[26]}$

\section{Conclusion}

From this review, 9 publications comprising 7 studies and 5 case reports were accessed. This shows that there is need for improvement in medication reporting in Africa especially as regards anaesthetic practice. Secondly reports exist for only three Africa countries as regards medication administration error in anaesthetic practice and there is need for other Africa countries to report and publish their own unique practice experience so that best practices can be shared.

The types of error were found to be either as a result of substitution or the dose of the medication. Causes of error have been reported to include look alike medication vial, fatigue and lack of colour coding for syringes. This can be adequately checked by double checking of all medication label by a minimum of two anaesthetist prior to administration, reducing Anaesthetics work load and introducing colour coding of syringes into national guidelines.

\section{Reference}

[1]. Institute of Medicine. To err is human: building a safer health system. Washington, DC: National Academy Press, 1999

[2]. Corrigan JM, et al.: Institution of medicine: shaping the future for health. To err is human: building a safer health system. Washington, DC: National academy press; 1999.

[3]. Lisby M, Nielsen LP, Mainz J. Errors in the medication process: frequency, type, and potential clinical consequences. Int J Qual Health Care 2005; 17:15-22.

[4]. Phillips DP, Christenfeld N, Glynn LM (1998) Increase in US medication-error deaths between 1983 and 1993. Lancet 351:643-4

[5]. Schachter M. The epidemiology of medicationerrors: how many, how serious? Br J ClinPharmacol. 2009 Jun;67(6):621-3. doi: 10.1111/j.1365-2125.2009.03418.x.

[6]. Barber ND, Dean BS. The incidence of medication errors and ways to reduce them. Clin Risk. 1998;4:103-6.

[7]. Bates DW, Cullen DJ, Laird N, Petersen LA, Small SD, Servi D, Laffel G, Sweitzer BJ, Shea BF, Hallisey R, et al. Incidence of adverse drug events and potential adverse drug events: implications for prevention. ADE prevention study group. JAMA. 1995;274:29-34.[PubMed]

[8]. Schneider PJ, Gift MG, Lee YP, Rothermich EA, Sill BE. Cost of medication-related problems at a university hospital. Am J Health Syst Pharm. 1995;52:2415-8.

[9]. Sabry NA, et al.: Role of the pharmacist in identification of medication related problems in the ICU: a preliminary screening study in an Egyptian teaching hospital. Aust. J. Basic \& Appl. Sci. 2009, 3(2):995-1003.

[10]. Leape LL, Brennan TA, Laird N, Lawthers AG, Localio AR, Barnes BA, et al. The nature of adverse events in hospitalized patien ts results of the Harvard Medical Practice Study II. N Engl J Med. 1991;324:377-84.

[11]. Brennan TA, et al.: Incidence of adverse events and negligence in hospitalized patients: results from the Harvard Medical Practice Study I. N Engl J Med 1991, 324:370-6

[12]. Camire E, Moyen E, Stelfox HT. Medication errors in critical care: Risk factors, prevention and disclosure. CMAJ.2009;180:93643.

[13]. Orser BA, Chen RJ, Yee DA. Medication errors in anaesthetic practice, a survey of 687 practitioners. Can J Anesth. 2001;48:13946.

[14]. Yamamoto M, Ishikawa S, Makita K. Medication errors in anesthesia: An 8-years retrospective-analysis at an urban university hospital. J Anesth.2008;22:248-52.

[15]. Raff M and James MFM (2003)An audit of anaesthetic record keeping. Southern African Journal of Anaesthesia \& Analgesia SouthernAfrican Journal of Anaesthesia\& Analgesia. http://www.ajol.info/index.php/sajaa/article/viewFile/96095/85450

[16]. Agalu A1, Ayele Y, Bedada W, Woldie M. Medicationadministrationerrors in an intensivecareunit in Ethiopia. . Int Arch Med. 2012 May 4;5(1):15.

[17]. Dean Franklin B, Vincent C, Schachter M, Barber N. The incidence of prescribing errors on hospital inpatients.An overview of the research methods.Drug Saf.2005;28:891-900.

[18]. Ogboli-Nwasor E. Medication errors in anaesthetic practice: a report of two cases and review of the literature. African Health Sciences. 2013;13(3):845-849. [PMC free article] [PubMed]

[19]. Mato CN, Fyneface-Ogan S. Drug Errors in Anaesthetic Practice: Case reports. Nigerian Journal of Medicine, Vol.12, No. 3, July September 2003

[20]. Nwasor EO, Sule ST, Mshelia DB. Audit ofmedication errors by anesthetists in North Western Nigeria. Niger J ClinPract2014;17:226-31

[21]. GordonP C, LlewellynR L, JamesM F M. Drug administration errors by South African anaesthetists- a surveyJuly 2006, Vol. 96, No. 7 SAMJ.

[22]. Gordon PC. Wrong drug administration errorsamongst anaesthetists in a South Africanteaching hospitalSouthern African Journal of Anaesthesia\& Analgesia - May 2004.

[23]. A A.O, A O.V.. A Retrospective Audit Of Drug Administration Errors During Elective Surgery. The Internet Journal of Anesthesiology.2009 Volume 25 Number 1.

[24]. Labuschagne M1, Robbetze W, Rozmiarek J, Strydom M, Wentzel M, Diedericks BJ, Joubert G.Errors in drug administration by anaesthetists in public hospitals in the Free State.S Afr Med J. 2011 May;101(5):324-7.

[25]. Llewellyn RL1, Gordon PC, Wheatcroft D, Lines D, Reed A, Butt AD, Lundgren AC, James MF. Drug administration errors: a prospective survey from three South African teaching hospitals. Anaesth Intensive Care. 2009 Jan;37(1):93-8

[26]. Amor M1, Bensghir M, Belkhadir Z, Ghannam A, Azendour H, DrissiKamili N, Maazouzi W. Medication errors in anesthesia: a Moroccan university hospitals survey. Ann Fr AnesthReanim. 2012 Nov;31(11):863-9 